\title{
Angiotensin II stimulates the synthesis of vascular endothelial growth factor through the p38 mitogen activated protein kinase pathway in cultured mouse podocytes
}

\author{
Young Sun Kang, Yun Gyu Park¹, Bo Kyung Kim¹, Sang Youb Han², Yi Hwa Jee, \\ Kum Hyun Han, Mi Hwa Lee, Hye Kyoung Song, Dae Ryong Cha, Shin Wook Kang ${ }^{3}$ \\ and Dae Suk Han ${ }^{3}$ \\ Department of Internal Medicine, Korea University Hospital, 516 Kojan-Dong, Ansan City, Kyungki-Do 425-020, Korea \\ ${ }^{1}$ Department of Internal Medicine and Biochemistry, College of Medicine, Korea University, Ansan City, Kyungki-Do, Korea \\ ${ }^{2}$ Department of Internal Medicine, College of Medicine, Inje University, Ilsan-Gu, Koyang City, Kyungki-Do, Korea \\ ${ }^{3}$ Department of Internal Medicine, College of Medicine, Yonsei University, Seodaemun-Gu, Seoul, Korea \\ (Requests for offprints should be addressed to D R Cha; Email: cdragn@unitel.co.kr)
}

\begin{abstract}
Angiotensin II (Ang-II) and vascular endothelial growth factor (VEGF) have an important role in the pathogenesis of diabetic nephropathy, but the signaling cascade of VEGF regulation in response to Ang-II in podocytes is largely unknown. In these experiments, we looked at the effect of Ang-II on the production of VEGF, and investigated whether VEGF production depends on the p38 mitogen activated protein kinase (MAPK) pathway in cultured mouse podocytes. Incubation of podocytes with Ang-II induced a rapid increase in VEGF mRNA expression and protein synthesis as well as its transcriptional activity in an Ang-II dose-dependent manner. To further define the role of angiotensin type 1 (AT1) and type 2 (AT2) receptors involved in Ang-II-mediated VEGF synthesis, the effects of selective AT1 and AT2 receptor antagonists were evaluated. Prior treatment with losartan significantly inhibited VEGF mRNA and protein synthesis induced by Ang-II, which suggests that the AT1 receptor is involved in Ang-II-mediated VEGF synthesis. Furthermore, stimulation of the cells with Ang-II increased both phosphorylation of p38 MAPK and MAP kinase kinase 3/6 (MKK3/6). Additionally, Ang-Il enhanced the DNA binding activity to CAMP response element binding protein (CREB) and phosphorylation of CREB. In addition, to investigate the role of p38 MAPK in Ang-II-induced VEGF synthesis, podocytes were pretreated with or without the p38 MAPK inhibitor, SB203580 for $24 \mathrm{~h}$ to observe whether Ang-II-mediated VEGF synthesis was inhibited by blocking p38 MAPK. The addition of SB203580 led to a marked inhibition of the increased VEGF mRNA and protein production induced by Ang-II in a dose-dependent manner. Taken together, these results suggest that Ang-II stimulates the synthesis of VEGF in podocytes and the production of VEGF induced by Ang-II is mediated, in part, through the activation of the p38 MAPK pathway.
\end{abstract}

Journal of Molecular Endocrinology (2006) 36, 377-388

\section{Introduction}

Diabetic milieu results in the increased expression of angiogenic growth factors in numerous tissues as a response to both hyperglycemia and tissue ischemia (Duh \& Aiello 1999, Ferrara 1999). It is generally accepted that podocytes are the major site of vascular endothelial growth factor (VEGF) production, and their regulation in VEGF expression may play an important role in diabetic nephropathy (Brown et al. 1992, Kretzler et al. 1998). Podocytes are unique cells in the glomerulus, cover the outer part of glomerular basement membrane and function as the final filtration barrier to protein loss.

There is now increasing data supporting a direct role for VEGF in the pathogenesis of diabetic nephropathy. $\mathrm{VEGF}$ is up-regulated from the early stage of diabetic nephropathy (Cooper et al. 1999). In vivo blockade of VEGF abolished hyperfiltration and suppressed the urinary albumin excretion rate in diabetic rats (De Vriese et al. 2001). In addition, VEGF may contribute to mesangial expansion and phagocytes infiltration (Clauss et al. 1990, Flyvbjerg et al. 2002). Taken together, these studies suggest that VEGF plays an important role in the pathogenesis of diabetic nephropathy.

Angiotensin II (Ang-II) plays an important role in the development of glomerulosclerosis (Leehey et al. 2000). There are several reports showing that Ang-II increases VEGF production in human mesangial cells and in vascular smooth muscle cells (Williams et al. 1995, Gruden et al. 1999, Pupilli et al. 1999). However, there is no report on whether Ang-II induces VEGF production in podocytes, which are the major source of VEGF 
synthesis in the glomerulus. Additionally, the signaling cascade of VEGF regulation in response to Ang-II in podocytes is largely unknown. Many studies have demonstrated protein kinase $\mathrm{C}$ activation in diabetic glomeruli and mesangial cells cultured under high glucose conditions (Craven \& DeRubertis 1989, Williams \& Schrier 1993, Zivadeh et al. 1995, Hoshi et al. 2002). Increased p38 mitogen activated protein kinase (MAPK) activity has been demonstrated in diabetic glomeruli (Kang et al. 2001), and Ang-II also activated p38 MAPK leading to the induction of fibronectin expression and cellular growth in rat mesangial cells (Reddy et al. 2002).

In this study, we examined the effects of Ang-II on VEGF mRNA expression and protein production in cultured mouse podocytes, and evaluated whether VEGF production depends on the p38 MAPK pathway. In addition, we examined the relationship between the p38 MAPK pathway and VEGF synthesis in cultured mouse podocytes.

\section{Materials and methods}

\section{Cell cultures}

A thermosensitive, SV40-transfected immortalized mouse podocyte cell line, a generous gift from Peter Mundel (Albert Einstein College of Medicine, New York, NY, USA), was used for this study. Cultivation of mouse podocytes that were conditionally immortalized with a temperature-sensitive variant of the SV40 large T antigen (tsA58) and whose activity can be increased by $\gamma$-interferon, was performed as described previously (Mundel et al. 1997). To propagate podocytes, cells were cultivated at $33^{\circ} \mathrm{C}$ and treated with $10-50 \mathrm{U} / \mathrm{ml}$ mouse recombinant $\gamma$-interferon (permissive condition), which increases the expression of the temperature-sensitive large $\mathrm{T}$ antigen and cell proliferation. To induce differentiation, podocytes were thermoshifted to $37^{\circ} \mathrm{C}$ and deprived of $\gamma$-interferon (non-permissive condition) for 14 days. Studies were performed using a podocytes cell line at 20-24 passages. Identification of podocytes was performed using RT-PGR for podocyte specific markers such as Wilms' tumor protein (WT-1). Differentiation of podocytes was determined on the basis of the expression of synaptopodin, which is a differentiation marker, using RT-PGR.

\section{Experimental design}

Differentiated podocytes were grown to sub-confluence in type 1 collagen-coated dishes (Iwaki, Tokyo, Japan) in growth media containing $10 \%$ fetal calf serum (FCS), $100 \mathrm{U} / \mathrm{ml}$ penicillin, and $0 \cdot 1 \mathrm{mg} / \mathrm{ml}$ streptomycin in RPMI 1640 medium, and then cultured for $24 \mathrm{~h}$ in a medium containing $5 \mathrm{mmol} / \mathrm{l} \mathrm{D}$-glucose and $1 \%$ FCS before being exposed to experimental conditions. In the Ang-II-stimulated group, different concentrations of Ang-II were added to the culture media at final concentrations of $1 \mathrm{nM}, 10 \mathrm{nM}$, and $100 \mathrm{nM}$. To define the mechanism of Ang-II-mediated VEGF synthesis, we used both the Ang-II receptor type 1 antagonist (losartan) and the Ang-II receptor type 2 antagonist (PD123319). When the effects of these drugs were tested, these compounds were added to podocytes one hour before Ang-II treatment. All experimental groups were cultured in triplicate and harvested at 6,24 and $72 \mathrm{~h}$ for extraction of total RNA and protein. The results are representative of those from three independent experiments.

To determine the effect of Ang-II on the p38 MAPK pathway, sub-confluent podocytes were cultured for $24 \mathrm{~h}$ in medium containing $5 \mathrm{mmol} / \mathrm{D}$-glucose and $1 \%$ FCS. Then, the cells were treated with Ang-II at a final concentration of $100 \mathrm{nM}$, and harvested after $30 \mathrm{~min}, 1 \mathrm{~h}, 6 \mathrm{~h}$ and $24 \mathrm{~h}$. In studies examining the role of the p38 MAPK pathway on VEGF synthesis, SB203580, which is a p38 MAPK inhibitor, was added to podocytes one hour before Ang-II treatment at final concentrations of 1 and $10 \mu \mathrm{M}$. Cells were harvested at $30 \mathrm{~min}, 1 \mathrm{~h}, 6 \mathrm{~h}$, and $24 \mathrm{~h}$ and then total RNA and protein were extracted. To avoid any confounding effects of serum on VEGF and proteins in the p38 MAPK pathway experiments, serum-free media were used. All experimental groups were cultured in triplicate. The results are representative of those from three independent experiments.

\section{RT-PCR}

Total RNA extraction was performed with a Trizol reagent and the cDNA was synthesized by a reverse transcription reaction using an RNA PGR kit (Applied Biosystems, Roche Inc., Foster City, CA, USA) in a $20 \mu \mathrm{l}$ mixture containing $1 \mu \mathrm{g}$ RNA, $50 \mathrm{mM} \mathrm{KCl}$, $10 \mathrm{mM}$ Tris/HCl, $5 \mathrm{mM} \mathrm{MgCl}$, $1 \mathrm{mM}$ of each dNTPs, oligo-(dT) primers, 20 units RNAse inhibitor and 50 units Moloney Murine Leukemia Virus (MuLV) reverse transcriptase. The reaction mixture was incubated for $60 \mathrm{~min}$ at $42{ }^{\circ} \mathrm{C}$, then heated at $90{ }^{\circ} \mathrm{C}$ for $7 \mathrm{~min}$ in a thermocycler (GeneAmp PCR system 9600, Perkin Elmer, Roche Molecular System, Branchburg, NJ, USA). Next, cDNA was amplified by 2.5 units AmpliTaq Gold polymerase in a $25 \mu \mathrm{l}$ reaction volume containing $10 \mathrm{mmol} / \mathrm{l}$ Tris-HCl (pH 8.3), $50 \mathrm{mmol} / \mathrm{l}$ $\mathrm{KCl}, 1.5 \mathrm{mmol} / \mathrm{l} \mathrm{MgCl}_{2}, 0.2 \mathrm{mmol} / \mathrm{l}$ deoxynucleoside triphosphate, and $30 \mathrm{pmol}$ of each primer. Sequence specific primers for VEGF, designed according to the mouse sequence (Gene bank number M95200), were used for the PGR. The nucleotide sequences of each primer are as follows: sense 5'- CAGGCTGCTGT AACGATGAA- ${ }^{\prime}$ and antisense ${ }^{\prime}$-AATGCTTTCTC CGCTCTGAA- ${ }^{\prime}$. As an internal control, $\beta$-actin was also amplified and nucleotide sequences for primers are 
as follows: sense 5'-TCATGAGGTAGTCCGTCAGG-3' and antisense 5'-TCTAGGCACGAAGGTGTG-3'. The PCR conditions were 40 cycles of denaturation at $95^{\circ} \mathrm{C}$ for $45 \mathrm{~s}$, annealing at $58{ }^{\circ} \mathrm{C}$ for $45 \mathrm{~s}$, and extension at $72{ }^{\circ} \mathrm{C}$ for $3 \mathrm{~min}$. The number of PGR cycles selected represents a point before the plateau of amplification products, as described previously (Cha et al. 2000, Kim et al. 2000). To confirm the identity of each PCR product, each of the electrophoresed PCR bands were extracted with a DNA extraction kit (Qiagen, Valencia, CA, USA) and sequenced using an $\mathrm{ABI}$ automated DNA sequencing system (ABI Genetic Analyzer 310; PRISM, Branchburg Park, NJ, USA). The RT-PGR products were separated on a $2 \%$ agarose gel with ethidium bromide staining by electrophoresis. After scanning at 300 d.p.i., densiometric analysis was performed for quantification using NIH (Bethesda, MA, USA) image analysis software (version $1 \cdot 61)$. The ratios of the concentration of $\beta$-actin to those of VEGF were evaluated.

\section{Transient transfection and luciferase reporter activity assay}

VEGF reporter plasmid containing firefly luciferase linked to VEGF promotor sequences was a generous gift from Dr P A D'Amore (Shima et al. 1996). Cells were plated onto 24-well plates at a density of $1 \times 10^{5}$ cells/well. Following $24 \mathrm{~h}$ growth, when cells were approximately 40 to $50 \%$ confluence, cells were transfected with $1 \mu \mathrm{g}$ VEGF reporter plasmid and $1 \mu \mathrm{g}$ plasmid containing Renilla luciferase driven by TK promotor using Superfect, as recommended by the manufacturer (Qiagen) for $24 \mathrm{~h}$. Then, media containing the transfection reagent were replaced with complete media without serum, and cells were treated with or without different concentrations of angiotensin II at final concentrations of $1 \mathrm{nM}, 10 \mathrm{nM}$ and $100 \mathrm{nM}$. After $24 \mathrm{~h}$, luciferase activity was determined using the dual luciferase assay system according to the manufacturer's instructions (Promega Corp., Madison, WI, USA). Relative light units from firefly luciferase activity were measured using a luminometer (Mono Light 2010, Analytical Luminescence Lab., San Diego, CA, USA). To control for differences in transfection efficiency from well to well, plasmid containing Renilla luciferase driven by TK promotor was included in each transfection and used for normalization.

\section{Western blotting}

Cells from the three experiments were lysed in lysis buffer $(150 \mathrm{mM} \mathrm{NaCl}, 50 \mathrm{mM}$ Tris-HCl, pH 8·0, $1 \mathrm{mM}$ phenylmethylsulfonylfluoride and $1 \%$ Triton X-100) with a sonicator, and total protein concentration was measured by the method of Bradford (Bio-Rad). Thirty micrograms protein were electrophoresed on a $10 \%$ sodium dodecyl sulfate-polyacrylamide gel under denaturing conditions. The proteins were transferred onto a polyvinylidene difluoride (PVDF) membrane (Immobilon-P, Millipore, Bedford, MA, USA) for $150 \mathrm{~min}$ at $250 \mathrm{~mA}$. After the filter was blocked by incubating the membranes with blocking solution $(1 \times$ PBS, $0 \cdot 15 \%$ Tween 20 and $5 \%$ non-fat milk) for $2 \mathrm{~h}$ at room temperature, the membranes were hybridized with each specific primary antibody overnight at $4{ }^{\circ} \mathrm{C}$. Anti-rabbit polyclonal VEGF antibody (Santa Cruz Biotechnology, Santa Cruz, CA, USA), polyclonal antibody to p38 MAPK, phospho-specific p38 MAPK, MAP kinase kinase 3/6 (MKK3/6), phospho-specific MKK3/6, cAMP response element binding protein (CREB), and phospho-specific CREB (New England Biolabs, Inc., Beverly, MA, USA) diluted 1:1000 were applied to the membrane. The filter was then washed four times with phosphate buffered slaine Tween-20 (PBST), and incubated with horseradish peroxidaseconjugated secondary antibody diluted 1:1000 for $60 \mathrm{~min}$ at room temperature. The detection of specific signals was performed using the ECL method (Amersham Biosciences Corp., Piscataway, NJ, USA). Equal amounts of protein loading were confirmed by Coomassie Blue staining of the gel.

\section{Enzyme-linked immunosorbent assay (ELISA)}

The amount of VEGF protein secreted by podocytes in culture medium was measured by commercially available quantitative sandwich enzyme immunoassay (R\&D Systems, Minneapolis, MN, USA). The assay method was designed to recognize both the 164 and 120 amino acid residue forms of mouse VEGF. The sensitivity of ELISA for VEGF was $3 \mathrm{pg} / \mathrm{ml}$. The intra-assay coefficient of variation was $4.7 \%$ and the interassay coefficient of variation was $6 \cdot 4 \%$. For measurement of secreted soluble VEGF in cultured medium, conditioned media were collected at the end of the treatment periods. All particulates were then removed by centrifugation at $4000 \times \boldsymbol{g}$ for $10 \mathrm{~min}$ and stored at $-20^{\circ} \mathrm{C}$ before the measurement of VEGF proteins. Supernatants were diluted five-fold with diluent solution according to the manufacturer's instructions. Fifty microliters of sample with an equal volume of diluent were dispensed in a 96-microwell plate, precoated with polyclonal antibody specific for mouse VEGF. The plates were incubated at room temperature for $2 \mathrm{~h}$, washed 5 times, and developed with $100 \mu \mathrm{l}$ color reagent per well. The intensity of the color was measured in an ELISA reader at $540 \mathrm{~nm}$.

\section{Electrophoretic mobility shift assay (EMSA)}

Podocytes were treated with $100 \mathrm{nM}$ angiotensin II for $8 \mathrm{~h}$. Nuclear extracts were prepared by the method of Dignam et al. (1983). Briefly, nuclear extracts (5 $\mu \mathrm{g}$ 
protein) were preincubated with poly $(\mathrm{dl}-\mathrm{dC}) \operatorname{zpoly}(\mathrm{dl}-\mathrm{dC})$ $(2 \mu \mathrm{g})$, dithiothreitol $(0.3 \mathrm{mM})$, and reaction buffer (12 mM Tris, $\mathrm{pH} 7 \cdot 9,2 \mathrm{mM} \mathrm{MgCl}_{2}, 60 \mathrm{mM} \mathrm{KCl}$, $0.12 \mathrm{mM}$ EDTA, and $12 \%$ glycerol) with or without CREB antiserum $(1-2 \mu \mathrm{l})$ for $30 \mathrm{~min}$ at $4{ }^{\circ} \mathrm{C}$. ${ }^{32} \mathrm{P}-$ Labeled oligonucleotide containing a consensus cAMP response element (GRE) sequence (5'-AGAGATTGCG TGAGGTCAGAGAGCTAG-3', Promega) was then added, and the reaction mixtures were incubated for $10 \mathrm{~min}$ at $37^{\circ} \mathrm{C}$. The reaction mixtures were then separated on a $4 \%$ nondenaturing polyacrylamide gel at $200 \mathrm{~V}$ for $2 \mathrm{~h}$. The gel was dried and autoradiographed. Anti-CREB antibody (Santa Cruz Biotechnology) was used for supershift. Unlabeled double-stranded oligonucleotides with one copy of GRE or Octl (5'-TGTCGAA
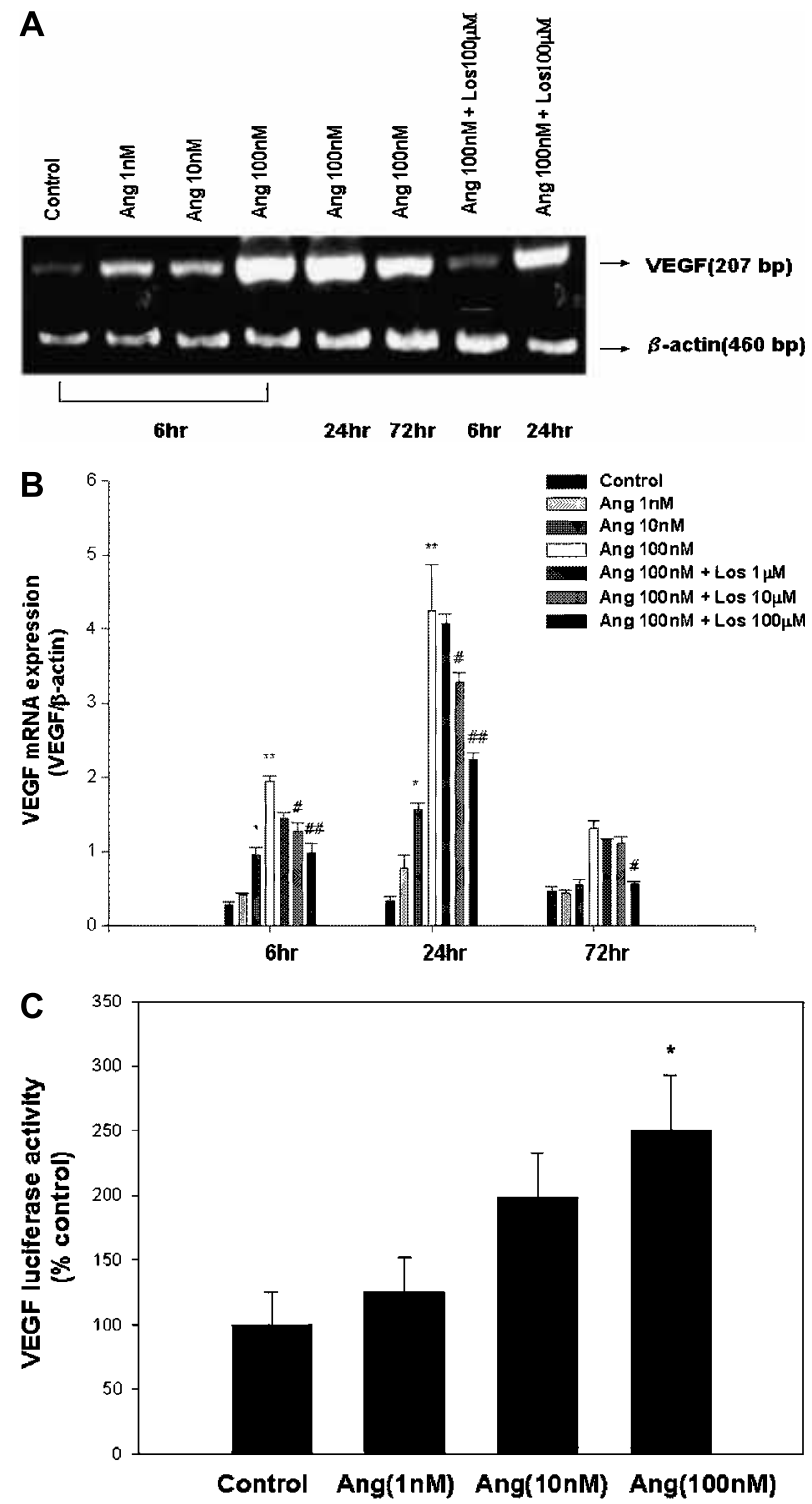

Journal of Molecular Endocrinology (2006) 36, 377-388
TGCAAATCACTAGAA-3', Promega) were used as competitor.

\section{Statistical analysis}

We used non-parametric analysis due to the small sample number. Results are expressed as means \pm S.D. Kruskall-Wallis was used for comparison of more than two groups, followed by Mann-Whitney $U$ test for comparison, using a microcomputer-assisted program with SPSS for Windows 10.0 (SPSS Inc., Chicago, IL, USA). $P<0.05$ was considered statistically significant.

\section{Results}

\section{Effects of Ang-II on VEGF mRNA and protein production}

When different concentrations of Ang-II were added to podocytes for $6 \mathrm{~h}$, VEGF mRNA expression incrementally increased in an Ang-II concentration-dependent

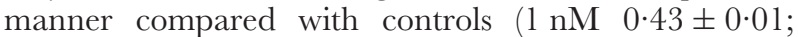
$10 \mathrm{nM} \quad 0.95 \pm 0 \cdot 10 ; \quad 100 \mathrm{nM} \quad 1.95 \pm 0.07 ; \quad$ control $0 \cdot 28 \pm 0 \cdot 04)$. For Ang-II concentrations of 1,10 and $100 \mathrm{nM}$, VEGF mRNA levels were time-dependently increased at $6 \mathrm{~h}$ and $24 \mathrm{~h}$ compared with that of the control group (group with Ang-II at $100 \mathrm{nM}$ : $6 \mathrm{~h}$ $1.95 \pm 0.07,24 \mathrm{~h} 4.25 \pm 0.62,72 \mathrm{~h} 1.32 \pm 0.09)$. As shown in Fig. 1, the stimulatory effect of Ang-II on VEGF mRNA levels showed significant increases at $6 \mathrm{~h}$ and $24 \mathrm{~h}$, and decreased at $72 \mathrm{~h}$, although its level was still higher compared with the control group.

To define the role of angiotensin type 1 (AT1) and type 2 (AT2) receptors involved in Ang-II-mediated

Figure 1 Effects of Ang-II and Ang-II type 1 receptor blockade (losartan) on the expression of VEGF mRNA and the effect of Ang-II on the transcriptional activity of VEGF in cultured podocytes. (A) Representative RT-PCR showing the $207 \mathrm{bp}$ product, which is identical to the 260 to 266 nucleotide of mouse alternatively spliced VEGF VE4 $_{16}$. In addition, a second $279 \mathrm{bp}$ product was also detected, but the density of the band was much weaker than the $207 \mathrm{bp}$ band. The $279 \mathrm{bp}$ band had an additional 72 nucleotides corresponding to the $\mathrm{VEGF}_{188}$ isoform. In this figure, only the major band of the RT-PCR product is shown. Podocytes were exposed to different concentrations of Ang-II with or without different concentrations of losartan for 6, 24 and $72 \mathrm{~h}$. (B) Densitometric analysis of RT-PCR data. Results are expressed as an optical density ratio of $\mathrm{VEGF} / \beta$-actin. Data are shown as means \pm S.D. of 3 independent experiments with triplicate dishes. (C) Podocytes were co-transfected with VEGF promotor-driven luciferase vector and TK-driven Renilla luciferase plasmid. Then cells were treated with Ang-II at concentrations of 1,10 or $100 \mathrm{nM}$ for $24 \mathrm{~h}$. VEGF reporter activity was normalized to Renilla luciferase activity. Data are shown as means \pm S.D. $n=6$ in each group. Ang, angiotensin II; Los, losartan. ${ }^{*} P<0.05$,

${ }^{* \star} P<0.001$ vs control. $\# P<0.05$, \#\#P<0.01 vs group treated with $100 \mathrm{nM}$ Ang-II. 
VEGF mRNA upregulation, podocytes were preincubated with losartan, a selective AT1 receptor antagonist and PD123319, a selective AT2 receptor antagonist under the influence of $100 \mathrm{nM} \mathrm{Ang-II.} \mathrm{Losartan} \mathrm{at} \mathrm{a}$ concentration of $1 \mu \mathrm{M}$ did not show a significant effect on VEGF mRNA expression. However, supplementation with 10 and $100 \mu \mathrm{M}$ losartan significantly inhibited the VEGF mRNA expression induced by Ang-II (in the group with $100 \mu \mathrm{M}$ losartan: $6 \mathrm{~h} 0.98 \pm 0 \cdot 14,24 \mathrm{~h}$ $2 \cdot 24 \pm 0 \cdot 09,72$ h $0 \cdot 56 \pm 0 \cdot 04$ ) (Fig. 1A,B).

\section{Effect of Ang-II on transcriptional activity of VEGF in cultured podocytes}

Since Ang-II stimulated VEGF mRNA and protein production, we wished to confirm using a luciferase reporter assay whether VEGF production induced by Ang-II actually increased its transcriptional activity. Podocytes transfected with VEGF-luciferase exhibited an increase in luciferase activity after stimulation with Ang-II in a dose-dependent manner. Although Ang-II treatment did not induce a significant increase in transcriptional activity at a concentration of 1 and $10 \mathrm{nM}$, VEGF transcriptional activity was significantly increased 2.5-fold at a concentration of $100 \mathrm{nM}$ compared with controls (Fig. 1C).

VEGF protein content in podocytes, evaluated by western blot, also increased in a concentration- and time-dependent manner after 6-h treatment with Ang-II (Fig. 2A,B). Densitometric analysis of the VEGF protein demonstrated a 1.9-fold (at $6 \mathrm{~h}$ ), 2.5-fold (at $24 \mathrm{~h}$ ) and $2 \cdot 7$-fold (at $72 \mathrm{~h}$ ) higher level compared with controls in the Ang-II (100 nM)-treated group. Losartan pretreatment $(100 \mu \mathrm{M})$ induced a reduction of $16 \%$ at $6 \mathrm{~h}, 44 \%$ at $24 \mathrm{~h}$, and $56 \%$ at $72 \mathrm{~h}$ in VEGF synthesis induced by Ang-II $(100 \mathrm{nM})$.

To confirm the effect of Ang-II on the upregulation of VEGF protein synthesis, the secretory types of VEGF were measured by the ELISA technique. Ang-II stimulation also increased the release of VEGF protein in a dose- and time-dependent manner. The levels of released VEGF after exposure for $6 \mathrm{~h}$ to $1 \mathrm{nM}, 10 \mathrm{nM}$ and $100 \mathrm{nM}$ Ang-II $\left(172 \pm 18 \mathrm{pg} / 10^{5} \mathrm{cells} / \mathrm{ml}, 222 \pm\right.$ $22 \mathrm{pg} / 10^{5} \mathrm{cells} / \mathrm{ml}$, and $342 \pm 28 \mathrm{pg} / 10^{5} \mathrm{cells} / \mathrm{ml}$ respectively) were significantly higher than the control cells $\left(94 \pm 11 \mathrm{pg} / 10^{5}\right.$ cells/ml) (Fig. 2C). For an Ang-II concentration of $100 \mathrm{nM}$, the time course of VEGF release showed $342 \pm 28 \mathrm{pg} / 10^{5}$ cells $/ \mathrm{ml}$ at $6 \mathrm{~h}, 424 \pm$ $20 \mathrm{pg} / 10^{5}$ cells $/ \mathrm{ml}$ at $24 \mathrm{~h}$, and $426 \pm 18 \mathrm{pg} / 10^{5}$ cells/ $\mathrm{ml}$ at $72 \mathrm{~h}$ compared with the level of controls $6 \mathrm{~h}$ $94 \pm 11 \mathrm{pg} / 10^{5} \mathrm{cells} / \mathrm{ml}, 24 \mathrm{~h} \quad 101 \pm 10 \mathrm{pg} / 10^{5}$ cells $/$ $\mathrm{ml}, 72 \mathrm{~h} 116 \pm 12 \mathrm{pg} / 10^{5}$ cells $/ \mathrm{ml}$ ).

Supplementation of culture media with losartan even at a concentration of $1 \mu \mathrm{M}$ showed significant inhibition of VEGF release. In comparison with the $100 \mathrm{nM}$ Ang-II treatment group the levels of VEGF release in the group
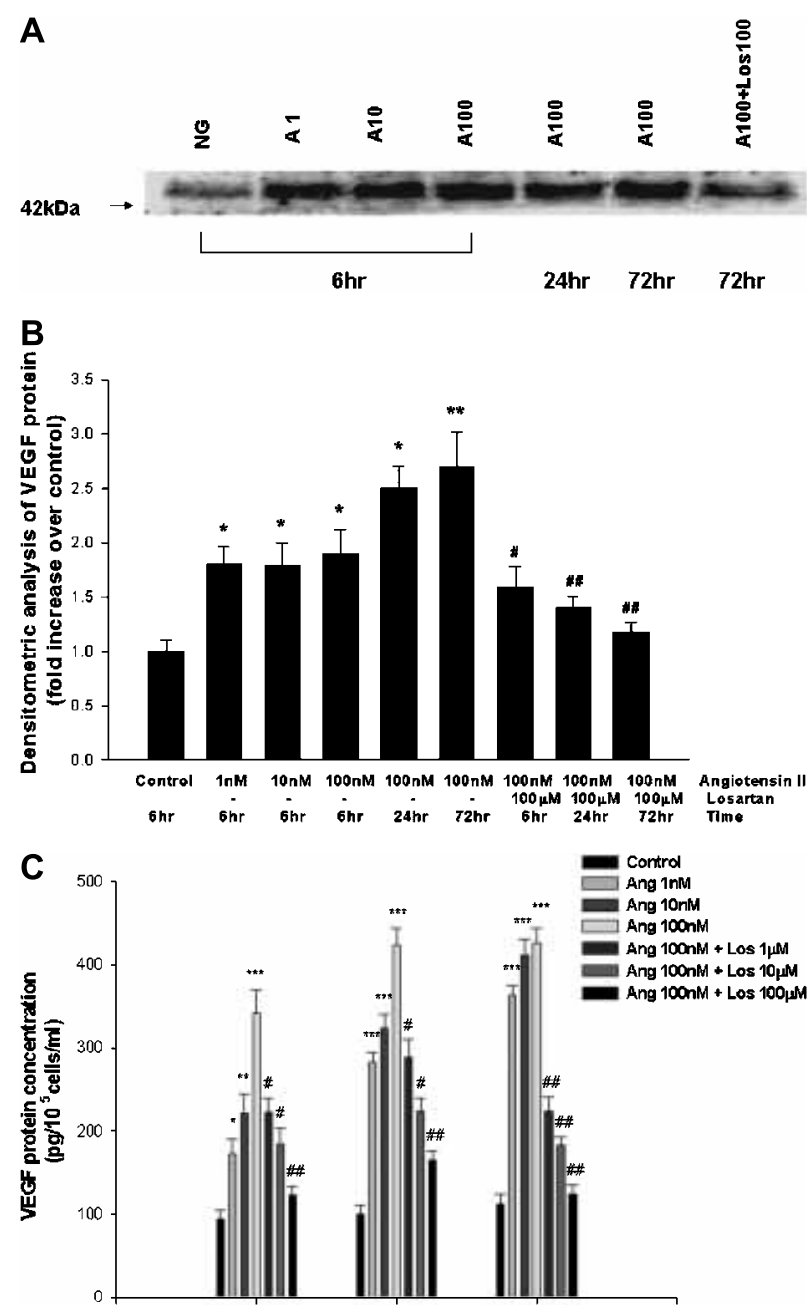

Figure 2 Effect of Ang-II and Ang-II type 1 receptor blockade (losartan) on VEGF protein in cultured podocytes. Podocytes were exposed to different concentrations of Ang-II with or without different concentrations of losartan for 6, 24 and $72 \mathrm{~h}$. (A) VEGF protein in podocytes was detected as a single band of approximately $42 \mathrm{kDa}$. Thirty micrograms proteins were electrophoresed on $10 \%$ sodium dodecyl sulfatepolyacrylamide gel. (B) Densitometric data are shown as means \pm S.D. of 3 independent experiments with triplicate dishes. (C) Secretory VEGF levels from culture supernatants were measured by ELISA. Data are shown as means \pm S.D. of 3 independent experiments with triplicate dishes.

Ang, angiotensin II; Los, losartan. ${ }^{\star} P<0.05$, ${ }^{* \star} P<0.01$, ${ }^{\star \star \star} P<0.001$ vs control. $\# P<0.05$, \#\#P<0.01 vs group treated with $100 \mathrm{nM}$ Ang-II.

with prior treatment with losartan $(100 \mu \mathrm{M})$ were significantly inhibited at $6 \mathrm{~h}$ (Ang-II $342 \pm 28 \mathrm{pg} /$ $10^{5}$ cells $/ \mathrm{ml}$ vs Ang-II+losartan $123 \pm 11 \mathrm{pg} / 10^{5}$ cells/ $\mathrm{ml}), 24 \mathrm{~h}$ (Ang-II $424 \pm 20 \mathrm{pg} / 10^{5} \mathrm{cells} / \mathrm{ml}$ vs Ang-II+ losartan $165 \pm 11 \mathrm{pg} / 10^{5}$ cells $/ \mathrm{ml}$ ), and $72 \mathrm{~h}$ (Ang-II $426 \pm 18 \mathrm{pg} / 10^{5}$ cells $/ \mathrm{ml}$ vs Ang-II+losartan $124 \pm$ $11 \mathrm{pg} / 10^{5}$ cells $/ \mathrm{ml}$ ) (Fig. 2G). However, PD123319, 

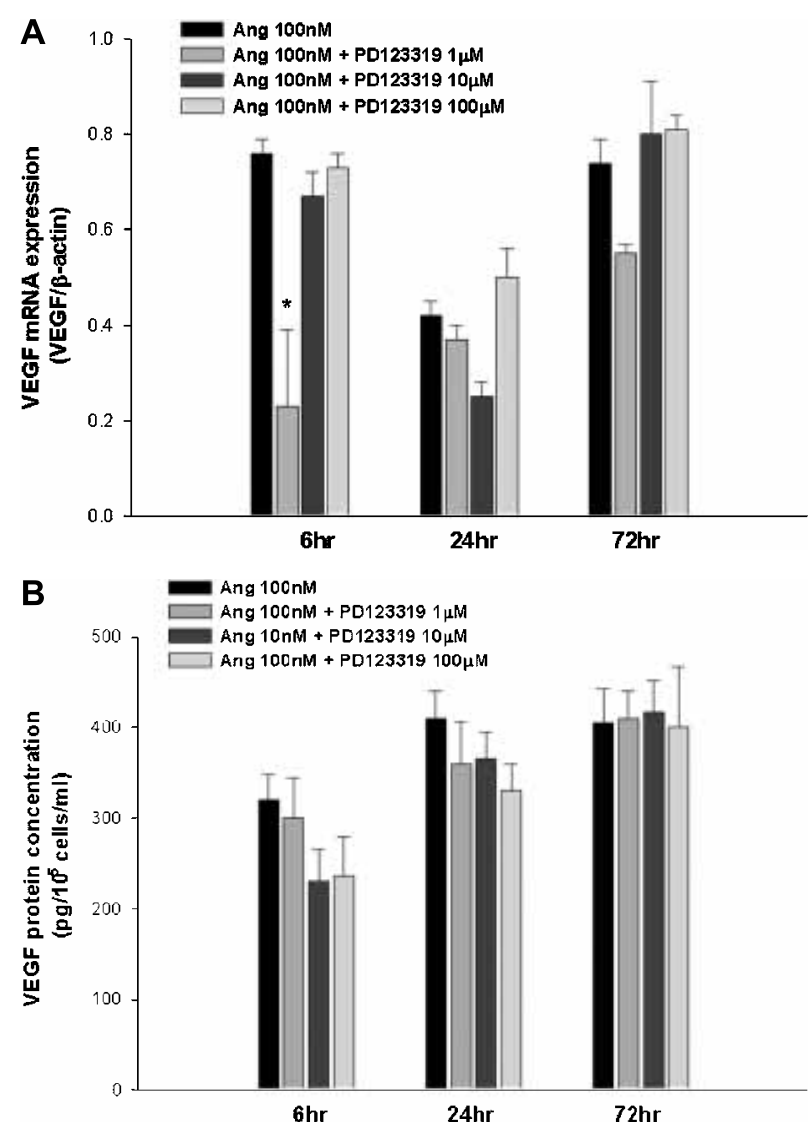

Figure 3 Effects of Ang-II type 2 receptor blockade (PD123319) on the expression of VEGF mRNA and protein secretion in cultured podocytes. Podocytes were exposed to $100 \mathrm{nM}$ Ang-II with or without different concentrations of PD123319 for 6, 24 and $72 \mathrm{~h}$. (A) Densitometric analysis of RT-PCR data. Results are expressed as an optical density ratio of $\mathrm{VEGF} / \beta$-actin. Data are shown as means \pm S.D. of 3 independent experiments with triplicate dishes. (B) Secretory VEGF proteins were measured in culture supernatant using ELISA, which recognizes both the 164 and 120 amino acid residue forms of mouse VEGF. Data are shown as means \pm S.D. of 3 independent experiments with triplicate dishes.

Ang, angiotensin II. ${ }^{\star} P<0.05$ vs group treated with $100 \mathrm{nM}$ Ang-II.

which is a selective AT2 receptor antagonist, did not show any significant effects on Ang-II-induced VEGF mRNA expression and protein production (Fig. 3).

\section{Effects of Ang-II on the activation of p38 MAPK}

Since Ang-II stimulated VEGF mRNA and protein production, we further evaluated whether VEGF production induced by Ang-II depends on the p38 MAPK pathway. We first examined the activation of p38 MAPK in response to Ang-II stimulation with $100 \mathrm{nM}$ Ang-II, which was the concentration of Ang-II
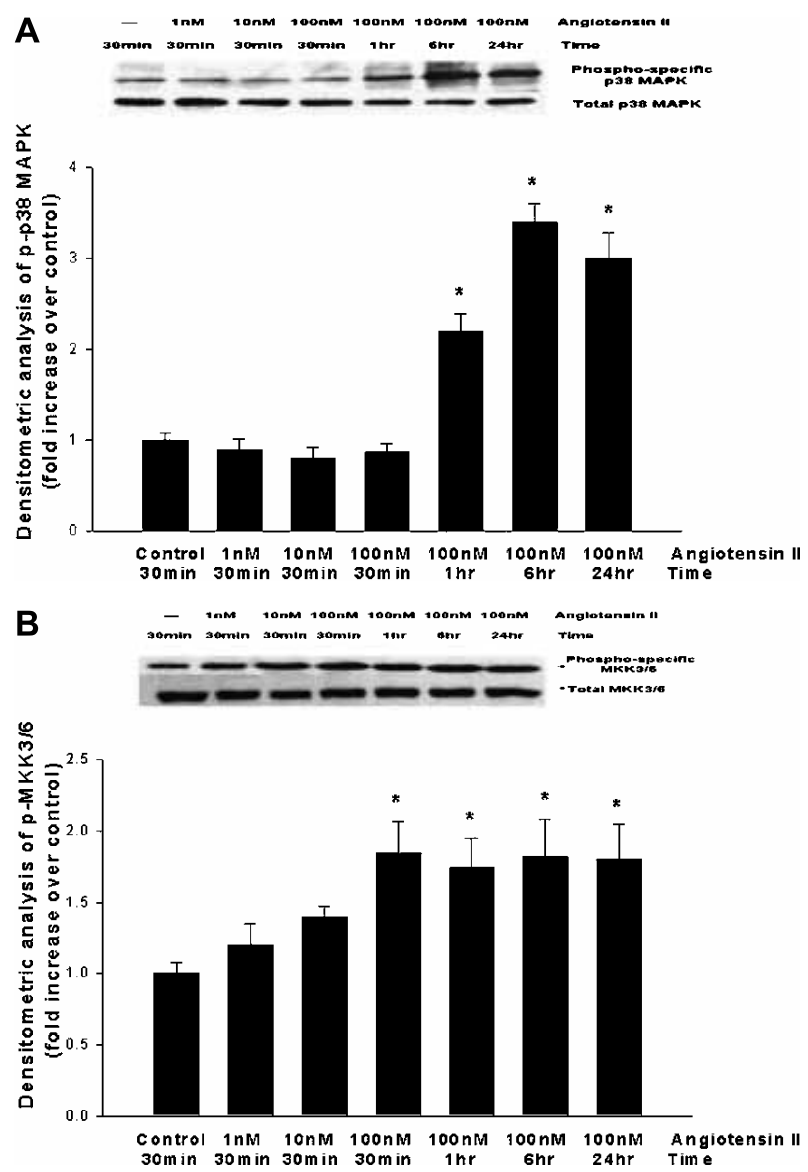

Figure 4 Effect of Ang-II on the activation of p38 MAPK protein and MKK3/6 protein in cultured podocytes. Different concentrations of Ang-II were added to the culture media at final concentrations of $1 \mathrm{nM}, 10 \mathrm{nM}$ and $100 \mathrm{nM}$ for $30 \mathrm{~min}$. At $100 \mathrm{nM}$ Ang-II, podocytes were harvested at $30 \mathrm{~min}, 1 \mathrm{~h}, 6 \mathrm{~h}$, and $24 \mathrm{~h}$. (A) Representative Western blot of phospho-specific p38 mitogen activated protein kinase (MAPK) protein in cultured podocytes in response to Ang-II treatment at $30 \mathrm{~min}$, $1 \mathrm{~h}, 6 \mathrm{~h}$ and $24 \mathrm{~h}$. (B) Representative Western blot of phospho-specific p38 mitogen activated protein kinase kinase $3 / 6(\mathrm{MKK} 3 / 6)$ protein in cultured podocytes in response to Ang-II treatment at $30 \mathrm{~min}, 1 \mathrm{~h}, 6 \mathrm{~h}$ and $24 \mathrm{~h}$. Densitometric data are shown as means \pm S.D. of 3 independent experiments with triplicate dishes. ${ }^{*} P<0.05$ vs control.

that induced maximal production of VEGF synthesis. The activation of p38 MAPK, assessed by measuring the levels of phospho-specific p38 MAPK, was found to increase rapidly in response to Ang-II after one hour. The maximal activity was observed at the 6 -h interval, densitometric analysis showed a $3 \cdot 4$ times higher level compared with controls (Fig. 4A). Following this peak, the level of p38 MAPK phosphorylation gradually decreased but remained higher than controls. However, the total p38 MAPK protein level did not differ among the groups.

www.endocrinology-journals.org 


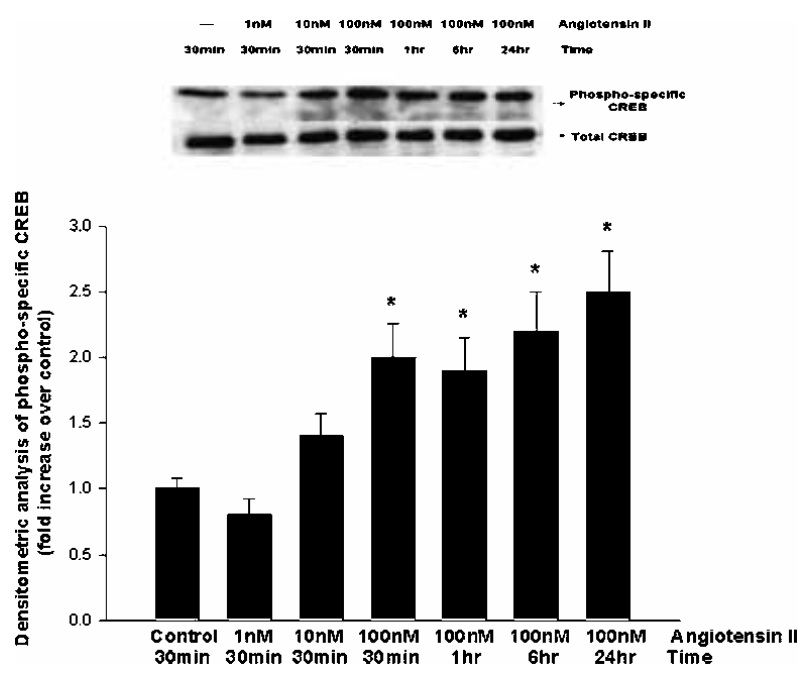

Figure 5 Effect of Ang-II on the activation of CREB protein in cultured podocytes. Different concentrations of Ang-II were added to the culture media at final concentrations of $1 \mathrm{nM}$, $10 \mathrm{nM}$ and $100 \mathrm{nM}$ for $30 \mathrm{~min}$. At $100 \mathrm{nM}$ Ang-II, podocytes were harvested at $30 \mathrm{~min}, 1 \mathrm{~h}, 6 \mathrm{~h}$, and $24 \mathrm{~h}$. Western blot was performed using both total CREB antibody and phospho-specific CREB antibody. Densitometric data are shown as means \pm S.D. of 3 independent experiments with triplicate dishes. ${ }^{*} P<0.05$ vs control.

\section{Effects of Ang-II on the activation of MKK3/6}

We next examined the effect of Ang-II on the activation of MKK3/6, which is an upstream activator of $\mathrm{p} 38$ MAPK. Phospho-specific MKK3/6 levels, an indication of MKK3/6 activation, peaked in response to Ang-II at $30 \mathrm{~min}$ and remained at higher levels throughout the study period (1.8-fold on average) (Fig. 4B). The increase in phospho-specific MKK3/6 levels occurred earlier than that in phospho-specific p38 MAPK levels. However, there was no significant difference in total MKK3/6 protein expression among the groups.

\section{Effects of Ang-II on the activation of CREB}

To determine whether the activation of the p38 MAPK pathway could induce a parallel increase in the activity of a p38 MAPK target transcription factor, we observed the activation of CREB, which is a known transcription factor for the synthesis of VEGF (Shima et al. 1996). CREB activation measured by the level of phosphspecific CREB demonstrated dose- and time-dependent increments after Ang-II stimulation. Maximum activity was observed at $24 \mathrm{~h}$ incubation, and densitometric analysis showed 2.5 times higher levels compared with controls (Fig. 5). However, total CREB protein expression was not changed according to the concentration of Ang-II and the stimulation time.
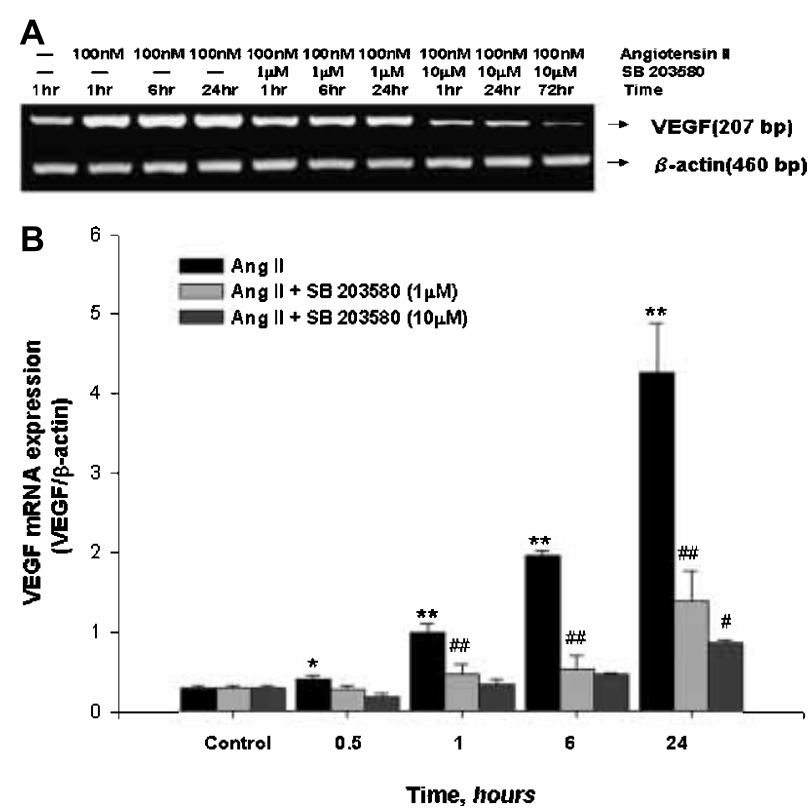

Figure 6 Effects of p38 MAPK inhibitor (SB203580) on the expression of VEGF mRNA induced by Ang-II in cultured podocytes. (A) Representative RT-PCR product. Podocytes were exposed to $100 \mathrm{nM}$ Ang-II with or without different concentrations of SB203580 for $30 \mathrm{~min}, 1 \mathrm{~h}, 6 \mathrm{~h}$ and $24 \mathrm{~h}$. (B) Densitometric analysis of RT-PCR data. Results are expressed as an optical density ratio of VEGF/ $\beta$-actin. Data are shown as means \pm S.D. of 3 independent experiments with triplicate dishes. ${ }^{\star} P<0.05,{ }^{\star *} P<0.01$ vs control. $\# P<0.05$ between SB203580-treated groups. \#\#P<0.01 vs group treated with $100 \mathrm{nM}$ Ang-II.

\section{Effects of p38 MAPK inhibitor (SB203580) on VEGF protein and mRNA expression increased by Ang-II stimulation}

We next examined whether p38 MAPK is involved in Ang-II-induced VEGF production since p38 MAPK, MKK3/6 and CREB were activated by Ang-II treatment. Thus, the inhibitory effect of SB203580 on Ang-II-induced VEGF synthesis was evaluated. With increasing concentrations of SB203580, Ang-II-induced VEGF mRNA expression significantly decreased, indicating that SB203580 acts as an inhibitor of VEGF synthesis. At a concentration of $10 \mu \mathrm{M}$ SB203580, VEGF mRNA expression was markedly suppressed from $30 \mathrm{~min}$ in response to $100 \mathrm{nM}$ Ang-II (30 min: Ang-II $0 \cdot 40 \pm 0 \cdot 03$ vs Ang-II+SB203580 0.17 $\pm 0 \cdot 05$; $1 \mathrm{~h}$ : Ang-II $0.98 \pm 0.11$ vs Ang-II+SB203580 0.33 0.06; $6 \mathrm{~h}:$ Ang-II $1.95 \pm 0.07$ vs Ang-II+SB203580 $0 \cdot 46 \pm 0 \cdot 02 ; \quad 24 \mathrm{~h}: \quad$ Ang-II $4 \cdot 25 \pm 0.62$ vs Ang-II+ SB203580 0.86 $\pm 0 \cdot 02$ ) (Fig. 6).

With western blot analysis, VEGF protein synthesis from podocytes also showed significant inhibition by pre-treatment with SB203580 from 30 min. Densitometric analysis demonstrated that SB203580 treatment 

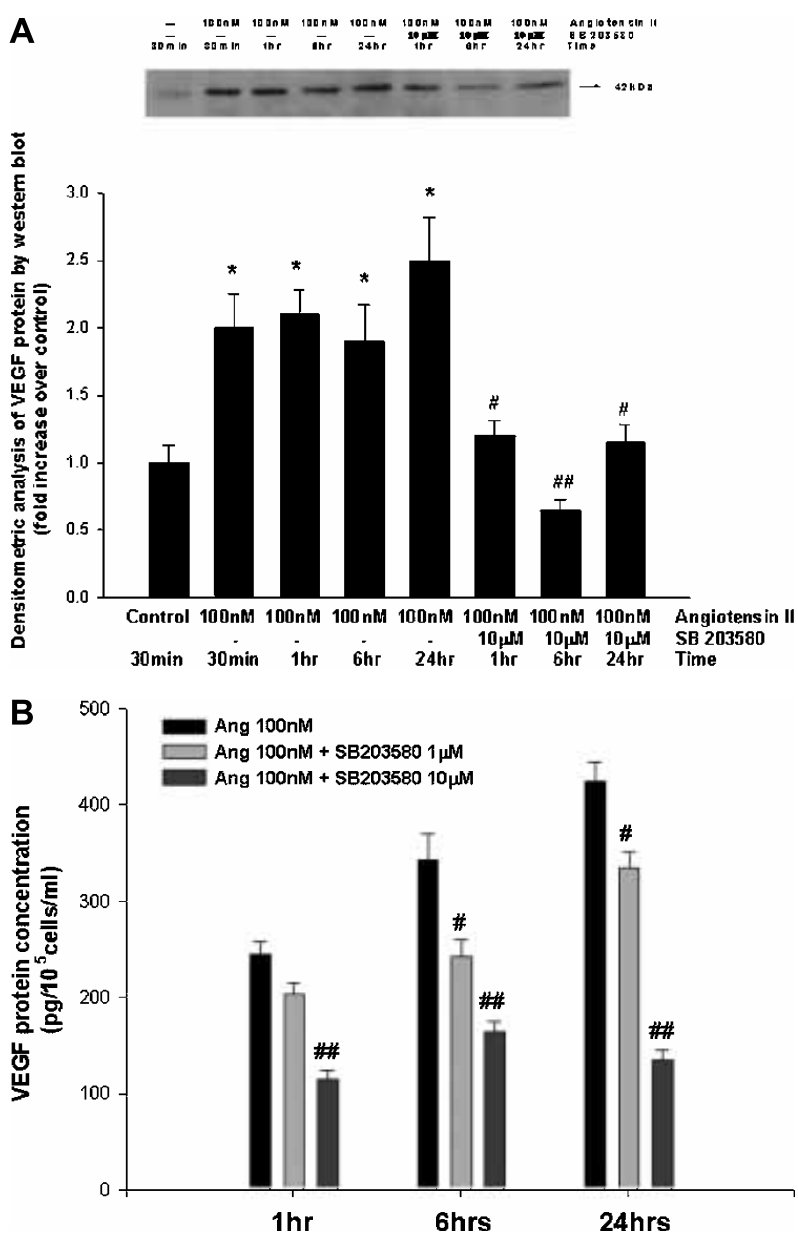

Figure 7 Effects of p38 MAPK inhibitor (SB203580) on the synthesis of VEGF protein in cultured podocytes. Podocytes were exposed to $100 \mathrm{nM}$ Ang-II with or without different concentrations of SB203580 for $30 \mathrm{~min}, 1 \mathrm{~h}, 6 \mathrm{~h}$, and $24 \mathrm{~h}$. (A) Representative western blot analysis showing the effect of p38 MAPK inhibitor (SB203580) on the cell content of VEGF protein in cultured podocytes. Thirty micrograms proteins were electrophoresed on $10 \%$ sodium dodecyl sulfatepolyacrylamide gel. (B) Secretory VEGF proteins were measured in culture supernatants using ELISA, which recognizes both the 164 and 120 amino acid residue forms of mouse VEGF. Densitometric data are shown as means \pm S.D. of 3 independent experiments with triplicate dishes. ${ }^{*} P<0.05$ vs control. $\# P<0.05, \# \# P<0.01$ vs group treated with $100 \mathrm{nM}$ Ang-II.

induced a reduction of $42 \%$ at $1 \mathrm{~h}, 66 \%$ at $6 \mathrm{~h}$, and $54 \%$ at $24 \mathrm{~h}$ in VEGF protein synthesis induced by Ang-II (Fig. 7A).

To confirm the inhibitory effect of SB203580 on VEGF protein release, secretory types of VEGF were measured by the ELISA technique. As illustrated in Fig. 7B, SB203580 pretreatment prevented Ang-IIinduced VEGF release in a concentration-dependent manner. Supplementation of culture media with
SB203580 even at a concentration of $1 \mu \mathrm{M}$ showed significant inhibition of VEGF release. The levels of VEGF release in the group with prior treatment with SB203580 $(10 \mu \mathrm{M})$ were significantly inhibited at $1 \mathrm{~h}$ (Ang-II $244 \pm 13 \mathrm{pg} / 10^{5}$ cells/ml vs Ang-II+SB203580 $114 \pm 9 \mathrm{pg} / 10^{5} \mathrm{cells} / \mathrm{ml}$ ), $6 \mathrm{~h}$ (Ang-II $342 \pm 28 \mathrm{pg} /$ $10^{5}$ cells/ml vs Ang-II+SB203580 $163 \pm 11 \mathrm{pg} /$ $10^{5} \mathrm{cells} / \mathrm{ml}$ ), and $24 \mathrm{~h}$ (Ang-II $424 \pm 20 \mathrm{pg} / 10^{5}$ cells/ $\mathrm{ml}$ vs Ang-II+SB203580 $134 \pm 11 \mathrm{pg} / 10^{5}$ cells/ml).

\section{Effect of Ang-II on electrophoretic mobility shift of CRE elements}

To confirm that Ang-II-induced phosphorylation of the p38 MAPK family proteins actually promotes the binding affinity of CREB, gel mobility-shift assays were performed by using an oligonucleotide probe containing the consensus sequence of CRE. When podocytes were treated with $100 \mathrm{nM}$ Ang-II, the CRE DNA-protein complex formation, (the binding of nuclear protein to CRE oligonucleotide containing consensus CRE (5'TGACGTCA- $\left.3^{\prime}\right)$ ), was increased in a time-dependent manner (Fig. 8A). Ang-II-induced phosphorylation of CREB was consistent with increased binding affinity of GREB (Fig. 8B). Anti-CREB antibody caused supershift, indicating the presence of CREB protein within the GRE DNA-protein complexes (Fig. 8C, lanes 1-4). ${ }^{32} \mathrm{P}-$ Labeled GRE oligonucleotide was incubated with nuclear extracts in the presence of 0.2-, 2- and 20-fold molar excess of unlabeled competitor. Ang-II-induced protein binding to the ${ }^{32} \mathrm{P}$-labeled CRE probe was inhibited by the unlabeled oligonucleotide containing the CRE sequence but not that containing the Oct-1 sequence (Fig. 8C, lanes 5-8). These findings suggest that angiotensin II enhances CRE-directed transcription of VEGF gene through increasing the DNA binding activity and phosphorylation of CREB.

\section{Discussion}

Among the many potential pathogenetic mechanisms responsible for the development of diabetic kidney disease, VEGF has been proposed to play a role in the development of diabetic renal changes in type 1 and type 2 diabetes (Duh \& Aiello 1999). More direct evidence of VEGF as a potential mediator of diabetic nephropathy was gained from studies using VEGF antibodies. Treatment with VEGF antibody was shown to ameliorate both the classical early features of diabetic renal disease, i.e. renal/glomerular hypertropy and hyperfiltration and also, more importantly, late renal changes (i.e. basement membrane thickening), with a tendency to reduce total mesangial volume in type 1 and 2 experimental models (De Vriese et al. 2001, Flyvbjerg et al. 2002). 

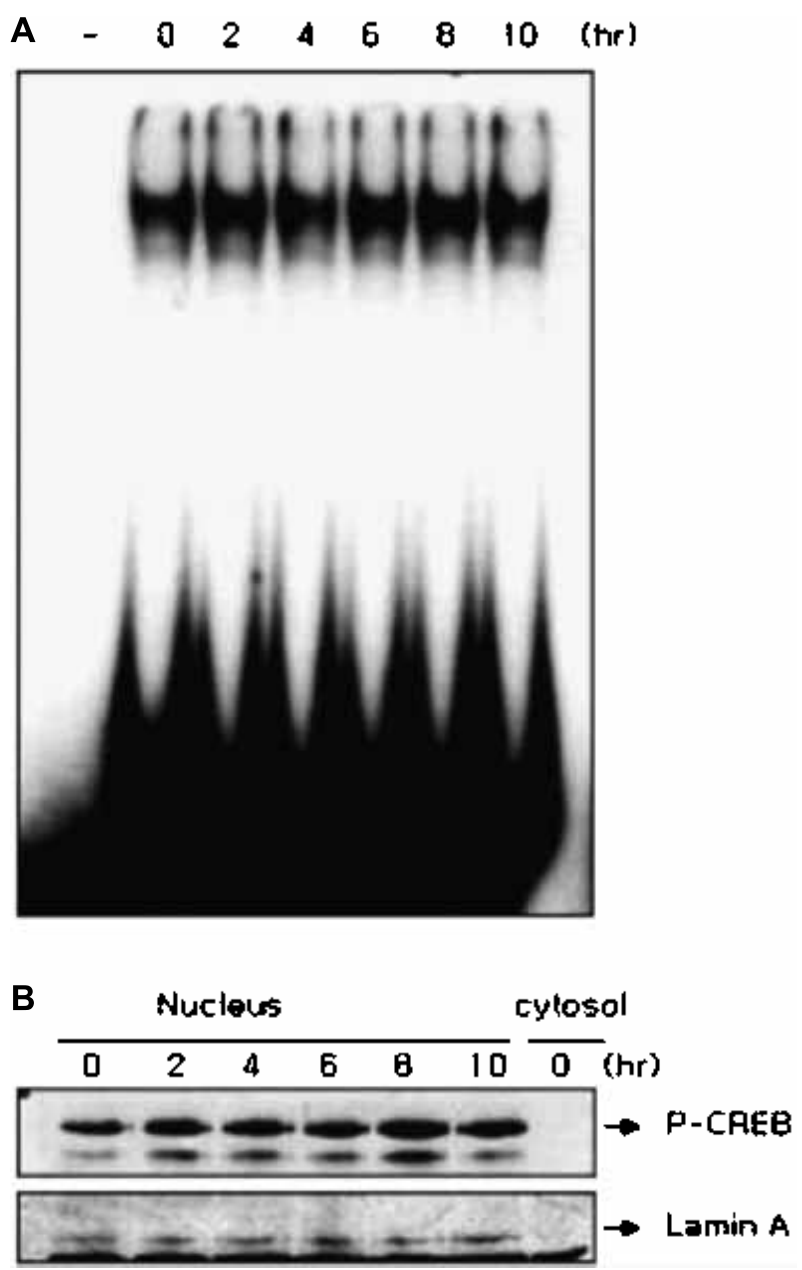

C
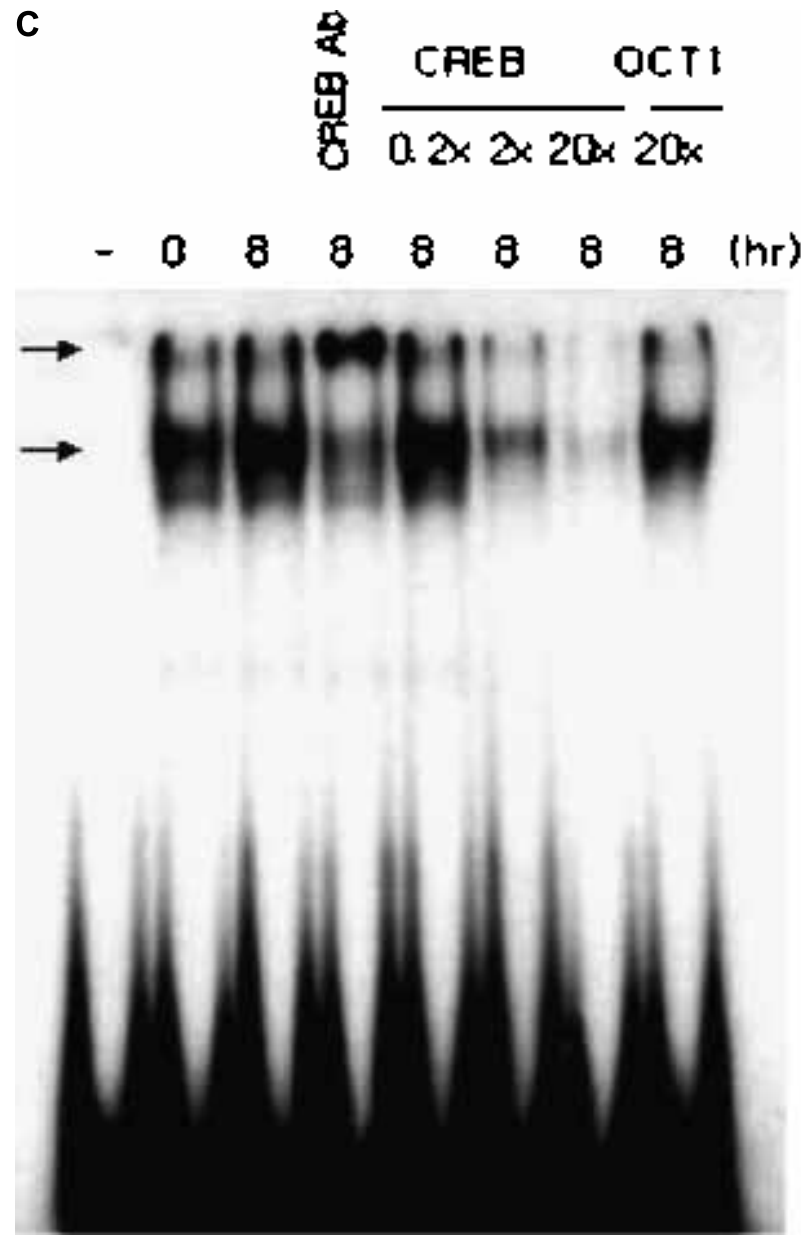

Figure 8 Effect of Ang-II on the binding affinity of CRE-binding protein. (A) Podocytes were treated with $100 \mathrm{nM}$ Ang-II for $2 \mathrm{~h}, 4 \mathrm{~h}$, $6 \mathrm{~h}, 8 \mathrm{~h}$ and $10 \mathrm{~h}$. Nuclear extract was incubated with ${ }^{32} \mathrm{P}$-labeled oligonucleotide containing the consensus cAMP response element (CRE) sequence, and the mixture was separated on a $4 \%$ nondenaturing polyacrylamide gel. (B) Podocytes were treated with $100 \mathrm{nM}$ Ang-II for $2 \mathrm{~h}, 4 \mathrm{~h}, 6 \mathrm{~h}, 8 \mathrm{~h}$ and $10 \mathrm{~h}$. Nuclear protein was extracted and immunoblot was performed using phospho-specific CREB antibody. (C) Podocytes were treated with $100 \mathrm{nM}$ Ang-II for $8 \mathrm{~h}$. The supershift assay was performed by incubating nuclear extract with or without antibody against CREB. ${ }^{32} \mathrm{P}$-Labeled CRE oligonucleotide was incubated with nuclear extracts in the presence of 0.2-, 2- and 20-fold molar excess of unlabeled competitor. The supershifted band is indicated by an arrow (upper band).

We have previously demonstrated that expression of VEGF increased in podocytes in diabetic patients in the early phase of diabetic kidney disease, and that urinary excretion of VEGF significantly increased according to the degree of proteinurea in both human and diabetic rats (Cha et al. 2000, 2004).

In the present study, VEGF mRNA expression increased after exposure to Ang-II in a concentrationdependent manner. This finding is similar to previous studies in mesangial cells and vascular smooth muscle cells in response to Ang-II (Williams et al. 1995, Kyriakis \& Avruch 2001). However, VEGF mRNA expression peaked at $24 \mathrm{~h}$ and then gradually decreased.
That Ang-II causes an early, but not sustained, release of VEGF in this study seems to argue against a role for VEGF in diabetic nephropathy, but prolonged activation of renin-angiotensin systems in the diabetic state in vivo may induce sustained VEGF overproduction for a longer period.

The effect of Ang-II on VEGF synthesis was maximal at an Ang-II concentration of $100 \mathrm{nM}$. The concentration of Ang-II required for the maximal effects on VEGF mRNA and protein secretion are consistent with previous reports in vascular smooth muscle cells and mesangial cells (Anderson et al. 1993, Williams et al. 1995). Similar to the findings with mRNA expression, 
VEGF protein content in podocytes and VEGF release also increased in a dose- and time-dependent manner. In addition, we observed that VEGF transcriptional activity also increased after stimulation with Ang-II in a dose-dependent manner. This result is in line with increased VEGF gene expression and protein production after stimulation with Ang-II. Interestingly, the stimulatory effects of Ang-II on VEGF mRNA and protein production were abolished not by pretreatment with PD123319, which is an AT2 receptor antagonist, but by pretreatment with losartan, which suggests that the AT1 receptor is involved in Ang-II-mediated VEGF synthesis.

P38 MAPK is a member of the MAPK family and plays an essential role in regulating many cellular processes, including inflammation, cell differentiation, cell growth and death (Ono \& Han 2000, Tian et al. 2000, Kyriakis \& Avruch 2001). There are many reports that Ang-II activates p38 MAPK in various kinds of cells including mesangial cells (Reddy et al. 2002) and vascular smooth muscle cells (Touyz et al. 2001). There is now a wealth of data supporting a direct role for p38 MAPK as a signaling pathway in the production of VEGF (Tanaka et al. 2000, Jung et al. 2001, Duyndam et al. 2003, Tokuda et al. 2003, Tsai et al. 2003). Therefore, in this study, we focused on the p38 MAPK pathway to identify the signaling pathways that mediate Ang-II-induced VEGF synthesis.

Since Ang-II stimulated VEGF production in a time-dependent manner with a peak level at the 24-h interval, we examined whether Ang-II activates the p38 MAPK pathway up to $24 \mathrm{~h}$. The activation of p38 MAPK occurred in response to Ang-II after $1 \mathrm{~h}$, peaking at $6 \mathrm{~h}$, and then gradually decreased. Although p38 MAPK activation began to decline at $24 \mathrm{~h}$, it was maintained at a significant level. In addition, Ang-II rapidly induced the activation of MKK $3 / 6$ and GREB.

Since the VEGF gene contains a CRE in its promoter region, activation of CREB can induce the transcript for VEGF (Shima et al. 1996). Braun et al. (2001) reported that the hypoxia responsive element and CRE are equally involved in the regulation of VEGF expression in various tissues in diabetic rats.

In our experiments, activation of CREB also occurred at $30 \mathrm{~min}$ of exposure, with the peak occurring at the 24-h interval following incubation. We also demonstrated that Ang-II augmented CREB DNA binding affinity in podocytes associated with rapid phosphorylation of CREB. Taken together, these results suggest that Ang-II activated the p38 MAPK pathway including CREB phosphorylation in podocytes.

Finally, we also examined the possible role of p38 MAPK in Ang-II-induced VEGF production. Pretreatment with the p38 MAPK inhibitor, SB203580, resulted in a dose-dependent decrease in Ang-II-induced VEGF mRNA transcription. SB203580 is widely used as a potent inhibitor of p38 MAPK and its primary activity is to inhibit p38 MAPK activity by binding to the ATP acceptor pocket (Young et al. 1997). However, it has recently been reported that SB203580 can also inhibit the phosphatidylinositol 3-kinase/protein kinase B pathway, cyclin G-associated kinase, and other apoptosis regulatory protein kinases (Lali et al. 2000, Godl et al. 2003). Thus, our results suggest that Ang-II-induced VEGF expression in podocytes is mediated, in part, through the p38 MAPK pathway. Furthermore, Ang-II-induced VEGF protein production was significantly suppressed by SB203580, suggesting that an Ang-II-p38 MAPK-VEGF pathway may exist and may be active in podocytes.

Although we did not observe whether Ang-II could increase VEGF production by podocytes in vivo, several studies have suggested a close relationship between the renin-angiotensin system (RAS) and VEGF in experimental animal models of diabetes. Treatment with Ang-II type 1 receptor antagonist attenuated renal structural injury and suppressed the VEGF expression in the glomeruli in streptozotocin-induced diabetic rats (Qin et al. 2003). In addition, angiotensin converting enzyme inhibitor prevented diabetes-induced podocyte injuries such as a decrease in podocyte number and foot process broadening, which results in structural and functional alterations in both type 1 and type 2 diabetic rats (Mifsud et al. 2001, Gross et al. 2003). Thus, we can postulate that Ang-II is involved in VEGF overexpression which accompanies diabetic nephropathy, and our in vitro data provide a potential mechanism for the beneficial effect of RAS blockade in diabetic nephropathy.

In conclusion, the present study provides evidence that Ang-II stimulated VEGF synthesis in cultured mouse podocytes, and that p38 MAPK activity increased after stimulation with Ang-II in association with both MKK3/6 and CREB activation. Furthermore, treatment with a potent p38 MAPK inhibitor abolished Ang-II-mediated VEGF production. Taken together, these results suggest that Ang-II-induced VEGF production was mediated, in part, through the p38 MAPK pathway in cultured mouse podocytes.

\section{Acknowledgements}

We thank Professor Peter Mundel and Sharon G Adler for the generous gift of the mouse podocyte cell line. We also thank Professor Patricia A D'Amore for the generous gift of the mouse VEGF promotor-luciferase. This work was supported, in part, by grant R01-2002000-00139-0 from the Basic Research Program of the Korea Science and Engineering Foundation, and by the Brain Korea 21 project in 2002. The authors declare that there is no conflict of interest that would prejudice the impartiality of this scientific work. 


\section{References}

Anderson PW, Yung SD \& Willa AH 1993 Angiotensin II causes mesangial cell hypertrophy. Hypertension 21 29-35.

Braun L, Kardon T, Reis-Porszasz ZS, Banhegyi G \& Mandl J 2001 The regulation of the induction of vascular endothelial growth factor at the onset of diabetes in spontaneously diabetic rats. Life Science $692533-2542$.

Brown LF, Berse B, Tognazzi K, Manseau EJ, Van de Water L, Senger DR, Dvorak HF \& Rosen S 1992 Vascular permeability factor mRNA and protein expression in human kidney. Kidney International 42 1457-1461.

Cha DR, Kim NH, Yoon JW, Jo SK, Cho WY, Kim HK \& Won NH 2000 Role of vascular endothelial growth factor in diabetic nephropathy. Kidney International Supplement 58 S104-S112.

Cha DR, Kang YS, Han SY, Jee YH, Han KH, Han JY, Kim YS \& Kim NH 2004 Vascular endothelial growth factor is increased during early stage of diabetic nephropathy in type II diabetic rats. Journal of Endocrinology 183 183-194.

Clauss M, Gerlach M, Gerlach H, Brett J, Wang F, Familletti PC, Pan YC, Olander JV, Connolly DT \& Stern D 1990 Vascular permeability factor: a tumor-derived polypeptide that induces endothelial cells monocyte procoagulant activity, and promotes monocyte migration. Foumal of Experimental Medicine 172 1535-1545.

Cooper ME, Vranes D, Youssef S, Stacker SA, Cox AJ, Rizkalla B, Casley DJ, Bach LA, Kelly DJ \& Gilbert RE 1999 Increased renal expression of vascular endothelial growth factor (VEGF) and its receptor VEGFR-2 in experimental diabetes. Diabetes 48 2229-2239.

Craven PA \& DeRubertis FR 1989 Protein kinase C is activated in glomeruli from streptozotocin diabetic rats. Possible mediation by glucose. Fournal of Clinical Investigation 83 1667-1675.

De Vriese A, Tilton RG, Elger M, Stephan CG, Kritz W \& Lameire NH 2001 Antibody against vascular endothelial growth factor improves early renal dysfunction in experimental diabetes. Fournal of the American Society of Nephrology 12 993-1000.

Dignam JD, Lebovitz RM \& Roedr RG 1983 Accumate transcription initiation by RNA polymerase II in a soluble extract from isolated mammalian nuclei. Nucleic Acids Research 11 1475-1489.

Duh E \& Aiello LP 1999 Vascular endothelial growth factor and diabetes; the agonist versus antagonist paradox. Diabetes 48 1899-1906.

Duyndam MC, Hulscher ST, van der Wall E, Pinedo HM \& Boven E 2003 Evidence for a role of p38 kinase in hypoxia-inducible factor-1-independent induction of vascular endothelial growth factor expression by sodium arsenite. Fournal of Biological Chemistry 278 6885-6895.

Ferrara N 1999 Role of vascular endothelial growth factor in regulation of angiogenesis. Kidney International 56 794-814.

Flyvbjerg A, Dagnaes-Hansen F \& De Vriese AS 2002 Amelioration of long-term renal changes in obese type 2 diabetes mice by a neutralizing vascular endothelial growth factor antibody. Diabetes 51 3090-3094.

Godl K, Wissing J, Kurtenbach A, Habenberger P, Blencke S, Gutbrod H, Salassidis K, Stein-Gerlach M, Missio A \& Daub H 2003 An efficient proteomics method to identify the cellular targets of protein kinase inhibitors. PNAS 100 15434-15439.

Gross ML, Ritz E, Schoof A, Helmke B, Parkman A, Tulp O, Munter K \& Amann K 2003 Renal damage in the SHR/N-cp type 2 diabetes model: comparison of an angiotensin converting enzyme inhibitor and endothelin receptor blocker. Laboratory Investigation 83 1267-1277.

Gruden G, Thomas S, Burt D, Zhou W, Chusney G, Gnudi L \& Viberti G 1999 Interaction of angiotensin II and mechanical stretch on vascular endothelial growth factor production by human mesangial cells. Fournal of the American Society of Nephrology $10730-737$.

Hoshi S, Nomoto K, Kuromitsu J, Tomari S \& Nagata M 2002 High glucose induced VEGF expression via PKC and ERK in glomerular podocytes. Biochemical and Biophysical Research Communications 290 177-184.

Jung YD, Liu W, Reinmuth N, Ahmad SA, Fan F, Gallick GE \& Ellis LM 2001 Vascular endothelial growth factor is upregulated by interleukin-1 beta in human vascular smooth muscle cells via the p38 mitogen-activated protein kinase pathway. Angiogenesis 49 155-162.

Kang SW, Adler SG, LaPage J \& Natarajan R 2001 p38 MAPK and MAPK kinase 3/6 mRNA and activities are increased in early diabetic glomeruli. Kidney International $60543-552$.

Kim NH, Jung HH, Cha DR \& Choi DS 2000 Expression of vascular endothelial growth factor in response to high glucose in rat mesangial cells. Fournal of Endocrinology 165 617-624.

Kretzler M, Schroppel B, Merkle M, Huber S, Mundel P, Horster M \& Schlondorff D 1998 Detection of multiple vascular endothelial growth factor splice isoforms in single glomerular podocytes. Kidney International Supplement 67 S159-S161.

Kyriakis JM \& Avruch J 2001 Mammalian mitogen-activated protein kinase signal transduction pathways activated by stress and inflammation. Physiological Reviewes 81 807-869.

Lali FV, Hunt AE, Turner SJ \& Foxwell BMJ 2000 The pyridinyl imidazole inhibitor SB203580 blocks phosphoinositide-dependent protein kinase activity, protein kinase B phosphorylation, and retinoblastoma hyperphosphorylation in interleukin-2 stimulated $\mathrm{T}$ cells independently of p38 mitogen-activated protein kinase. Journal of Biological Chemistry 275 7395-7402.

Leehey DJ, Singh AK, Alavi N \& Singh R 2000 Role of angiotensin II in diabetic nephropathy. Kidney International Supplement 58 S93-S98.

Mifsud SA, Allen TJ, Bertram JF, Hulthen UL, Kelly DJ, Cooper ME, Wilkinson-Berka JL \& Gilbert RE 2001 Podocyte foot process broadening in experimental diabetic nephropathy: amelioration with renin-angiotensin blockade. Diabetologia 44 878-882.

Mundel P, Reiser J, Zuniga Mejia Borja A, Pavenstadt H, Davidson GR, Kriz W \& Zeller R 1997 Rearrangements of the cytoskeleton and cell contacts induce process formation during differentiation of conditionally immortalized mouse podocyte cell lines. Experimental Cell Research 236 248-258.

Ono K \& Han J 2000 The p38 signal transduction pathway: activation and function. Cellular Signalling 12 1-13.

Pupilli C, Lasagni L, Romagnani P, Bellini F, Mannelli M, Misciglia N, Mavilia C, Vellei U, Villari D \& Serio M 1999 Angiotensin II stimulates the synthesis and secretion of vascular permeability factor/vascular endothelial growth factor in human mesangial cells. Fournal of the American Society of Nephrology $10245-255$

Qin J, Zhang Z, Liu J, Sun L, Hu L, Cooper ME \& Cao Z 2003 Effects of the combination of an angiotensin II antagonist with an HMG-CoA reductase inhibitor in experimental diabetes. Kidney International 64 565-571.

Reddy MA, Adler SG, Kim YS, Lanting L, Rossi J, Kang SW, Nadler JL, Shahed A \& Natarajan R 2002 Interaction of MAPK and 12-lipoxygenase pathway in growth and matrix protein expression in mesangial cells. American Fournal of Physiology Renal Physiology 283 F985-F994.

Shima DT, Kuroki M, Deutsch U, Ng YS, Adamis AP \& Amore PAD 1996 The mouse gene for vascular endothelial growth factor. Fournal of Biological Chemistry 271 3877-3883.

Tanaka T, Kanai H, Sekiguchi K, Aihara Y, Yokoyama T, Arai M, Kanda T, Nagai R \& Kurabayashi M 2000 Induction of VEGF gene transcription by IL-1 beta is mediated through 
stress-activated MAP kinases and Spl sites in cardiac myocytes. fournal of Molecular and Cellular Cardiology 32 1955-1967.

Tian W, Zhang Z \& Cohen DM 2000 MAPK signaling and the kidney. American fournal of Physiology Renal Physiology 279 F593-F604.

Tokuda H, Hatakeyama D, Shibata T, Akamatsu S, Oiso Y \& Kozawa O 2003 p38 MAP kinase regulates BMP-4-stimulated VEGF synthesis via p70 S6 kinase in osteoblasts. American Journal of Physiology Endocrinology Metabolism 284 E1202-E1209.

Touyz RM, He G, El Mabrouk M, Diep Q, Mardigyan V \& Schiffrin EL 2001 Differential activation of extracellular signal-regulated protein kinase $1 / 2$ and p38 mitogen activated-protein kinase by AT1 receptors in vascular smooth muscle cells from Wistar-Kyoto rats and spontaneously hypertensive rats. Fournal of Hypertension 19 553-559.

Tsai PW, Shiah SG, Lin MT, Wu CW \& Kuo ML 2003 Up-regulation of vascular endothelial growth factor $\mathrm{C}$ in breast cancer cells by heregulin-beta1. A critical role of p38/nuclear factor-kappa B signaling pathway. Foumal of Biological Chemistry $2785750-5759$.

Williams B \& Schrier RW 1993 Glucose-induced protein kinase C activity regulates arachidonic acid release and eicosanoid production by cultured glomerular mesangial cells. Fournal of Clinical Investigation 92 2889-2896.

Williams B, Quinn Baker A, Gallacher B \& Lodwick D 1995 Angiotensin II increases vascular permeability factor gene expression by human vascular smooth muscle cells. Hypertension 25 913-917.

Young PR, McLaughlin MM, Kumar S, Kassis S, Doyle ML, McNulty D, Gallagher TF, Fisher S, McDonnell PC, Carr SA, Huddleston MJ, Seibel G, Porter TG, Livi GP, Adams JL \& Lee JC 1997 Pyridinyl imidazole inhibitors of p38 mitogen-activated protein kinase bind in the ATP site. Fournal of Biological Chemistry 272 12116-12121.

Ziyadeh FN, Fumo P, Rodenberger CH, Kuncio GS \& Neilson EG 1995 Role of protein kinase C and cyclic AMP/protein kinase A in high glucose-stimulated transcriptional activation of collagen alpha 1 (IV) in glomerular mesangial cells. Foumal of Diabetes Complications 9 255-261.

Received in final form 26 January 2006

Accepted 1 February 2006

Made available online as an Accepted Preprint 6 February 2006 